\section{Frequency of self-reported sexual aggression \\ Frequency of self-reported sexual aggression
and victimization in Brazil: a literature review}

\author{
Frequência de agressão e vitimização sexual \\ autorreportada no Brasil: uma revisão \\ da literatura
}

\author{
de la literatura
}
Frecuencia de la agresión y la victimización
sexual autoinformada en Brasil: una revisión
Frecuencia de la agresión y la victimización
sexual autoinformada en Brasil: una revisión

(n)

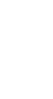


For decades, the lack of official data on rape has posed a challenge for public health researchers in Brazil. Two official documents published in 2013 and 2014 had great repercussions in the media and social networks, fueling the discussion on rape in the country. The first report was published by the Brazilian National Information System for Public Safety (SINESP) 1 and provided data on rape based on law enforcement records in municipalities with more than 100,000 inhabitants. The second document was prepared by the Brazilian Institute of Applied Economic Research (IPEA) 2 and provides data on rape cases assisted by public health services. Based on law enforcement and medical records, they were among the first documents to report official nationwide data on the occurrence of rape, thereby facilitating comparisons among the country's five major regions and identification of increasing or decreasing trends in the preceding years. However, the reports showed several limitations. From a public health perspective, they should be seen neither as the yardstick for studying rape nor as the only source of information for policymakers in Brazil.

The first limitation is that both reports only recorded victims that had turned to the police 1 or the public health care system ${ }^{2}$. According to self-report studies in Brazil, only $2.4 \%$ of female and $0 \%$ of male sexual assault victims reported their cases to law enforcement 3 . Victims' access to the health system is also limited 4 , and there is evidence that many health professionals are unqualified to identify and appropriately refer victims to law enforcement 5,6. This explains why the cases identified and officially recorded by public health services are much fewer than those obtained through self-report questionnaires in the same services 7 . Self-report studies also include other forms of sexual aggression (e.g., sexual contact, sexual coercion) in addition to rape, which partly explains why self-report studies provide higher rates than official records. However, studies suggest that rape is highly underreported, especially in middle and low-income countries, and that "official" data on rape victims represent only a small minority of actual cases 8 . According to a recent report in the United States, the number of rape incidents identified by the $\mathrm{Na}$ tional Intimate Partner and Sexual Violence Survey in 2010 (1,270,000 cases) was nearly 15 times higher than the figures reported to the Federal Bureau of Investigation (FBI) in the same year $(85,593){ }^{9}$. Middle-income countries like South Africa and India show similar patterns 10,11. Even if underreporting occurs worldwide, the problem may prove even more critical in middle and low-income countries, due to lack of appropri- ate infrastructure to support crime reporting 10 and lack of trust in the justice system. The Brazilian Ministry of Health estimates that less than $10 \%$ of rape cases are reported to the police 12 . In fact, according to the SINESP report 1 , rape incidence in 2012 ranged from 0.27 to 61.0 per 100,000 inhabitants across Brazil's states. Absolute rape figures ranged from 2 in Acre State to 12,888 in São Paulo State, rates that appear to be grossly underestimated. In addition, the IPEA report suggests that at least among adults, the more the act resembles the "common sense" definition of rape (i.e., an act perpetrated by a male stranger against a female victim in a public space, at night and using force), the more likely the victim seeks medical assistance and becomes part of official medical records. According to the same report 2 , among adult victims, $97 \%$ of aggressors were male and $98 \%$ of victims were female. The perpetrator was unknown to the victim in $61 \%$ of cases. Of those, $61 \%$ involved physical force and at least $50 \%$ occurred on the street. Nearly $70 \%$ of adult rape cases occurred between 6:00 PM and 6:00 AM. These data differ sharply from those provided by studies in the general population or convenience samples, where both women and men report sexual victimization by intimate partners, occurring in domestic settings, and where other forms of coercion were applied (e.g., taking advantage of victim's incapacitated state) 13,14. Besides the underreporting problem, the IPEA report did not included victims treated at private clinics, which mainly serve the middle and upper classes in Brazil.

A second limitation is the way sexual aggression is defined in the IPEA and SINESP reports. Both reports adopt the legal definition of rape. Article 213 of the Brazilian Penal Code 15 defines rape as "the use of violence or serious threat to force someone to have sexual intercourse or to commit or force someone to engage in other lewd and lascivious acts". Cases that involve alcohol or drug intoxication by the victim are addressed by an additional category called "rape of a vulnerable person” (Section 217-A, $\$ 1$ ), defined as "to have sexual intercourse or commit other lewd acts with someone who lacks the necessary insight into such acts, or who cannot resist for any other reason". However, the law enforcement system provides limited information for researchers. Public health professionals are usually interested in a broad range of nonconsensual sexual activities, defined as sexual aggression, that threaten the reproductive health of women and men, even when rape is not consummated. Sexual aggression constitutes unwanted sexual contact (e.g. kissing, rubbing against another person's private parts) up to any form of penetration (e.g. into a 
woman's vagina or someone's anus or mouth). Such acts can be perpetrated through different aggressive strategies, such as verbal coercion, the use or threat of physical force, or exploitation of the victim's incapacitated state 16 . This broader definition results in higher rates of sexual aggression than the official records, but offers some advantages. It enables researchers to identify a continuum from less to more severe forms of sexual aggression in a society. It also challenges the common sense belief that rape is limited to violent sexual assault by a stranger in a dark place 17 and shows that it can be perpetrated by anyone, including intimate partners, through more subtle coercive strategies rather than physical force 18 .

Therefore, two important challenges for public health researchers are the detection of "hidden" rape cases and identification of other forms of sexual aggression. Self-report and more inclusive definitions of sexual aggression are strategies to deal with these challenges. Self-report interviews or questionnaires are simple and convenient to apply and are one of the few available methods to assess private behaviors such as sexual behavior ${ }^{19}$. Although data based on selfreport can be subject to recall bias, social desirability bias, shame, and denial 20 , self-reporting is still an effective method for assessing "obscure figures", providing a more trustworthy picture of rape levels 18 . The method's limitations can be reduced through an atmosphere of trust and respect, and the assurance of voluntary participation and anonymity. As a result, studies based on self-reporting have identified alarming rates of sexual aggression, confirming the huge gap between official data and the real scope of rape.

\section{The current study}

Although the SINESP and IPEA reports represent important strides in research on rape in Brazil, both documents have some limitations. They are unable to identify the "obscure figures" of rape and other forms of nonconsensual sexual activities. In order to obtain more realistic incidence rates for sexual aggression, researchers often use self-report methods and focus on a broad spectrum of coercive sexual acts rather than rape only. The current study thus aims to investigate the frequency of sexual aggression in Brazil through self-report by victims and perpetrators. A literature review was conducted on studies that identified the prevalence or incidence of self-reported sexual aggression and victimization among women and men over age 14 (the age of consent in Brazil).

\section{Method}

\section{Databases and key word search strategy}

Electronic searches were conducted in SciELO, MEDLINE via PubMed, Scopus, PsycINFO, and Web of Knowledge. Google Scholar and reference checking were also used to identify potential articles in the gray literature. Target descriptors were intimate partner violence OR sexual aggression OR sexual violence OR sexual coercion OR sexual assault OR rape AND Brazil in both English and Portuguese. To keep the review manageable, $\mathrm{PhD}$ dissertations were not included. No time limit was specified for the search.

The review included: (1) studies on sexual aggression in females and males over age 14 and (2) studies that included any form of sexual aggression (e.g., from unwanted sexual touching to rape) and any form of coercive strategy (e.g., verbal coercion, physical force or threat, taking advantage of the victim's incapacitated state) committed by anyone known or unknown to the victim. Publications in English, French, German, Portuguese, and Spanish were potentially considered for the review. Exclusion criteria were: (1) studies on sexual aggression/rape in mixed samples of children, adolescents, and adults, where it was unfeasible to separate victimization of adults, adolescents, and children (except for two studies that included pregnant women older than 13 years 21,22); (2) when rates of sexual aggression were presented in combination with other forms of aggression (e.g., physical and psychological), thus preventing the separate identification of rates of sexual aggression individually; and (3) studies on sexual harassment, forced marriage or cohabitation, forced abortion, genital mutilation, obligatory inspection for virginity, forced prostitution, and sex trafficking. According to the World Health Organization (WHO), the latter terms fall under the broad definition of sexual violence ${ }^{8}$. However, the present study focused on nonconsensual sexual activities from unwanted sexual contact to any form of penetration, previously defined as sexual aggression.

The search was conducted by one researcher and repeated by the same individual before submission to verify accuracy. All studies that met the inclusion criteria were selected for the review, regardless of their methodological rigor. Methodological limitations will be addressed later in the discussion. 


\section{Results}

A total of 595 studies were initially selected from the literature databases. Two additional articles were found through reference checking and three through the Google search engine. Figure 1 summarizes the selection of studies. Forty-one articles met the inclusion criteria and were selected for the review. All studies were cross-sectional, and most were conducted after the year 2000. In order to understand possible variation between studies in the rates of sexual aggression, the respective methods were also analyzed for time frame, target population, study location, sampling methods, and definitions.
Self-reported sexual victimization in women and men

\section{- Time window}

Of the 41 selected studies, 27 provided lifetime prevalence data on sexual victimization, and six provided incidence data for the previous year (Table 1). Other studies collected information on sexual victimization using different time frames, such as after age 14 years, after age 15, after age 16 , after age 18, during pregnancy, since starting university, and during the intimate relationship.

Figure 1

Selection flow diagram.

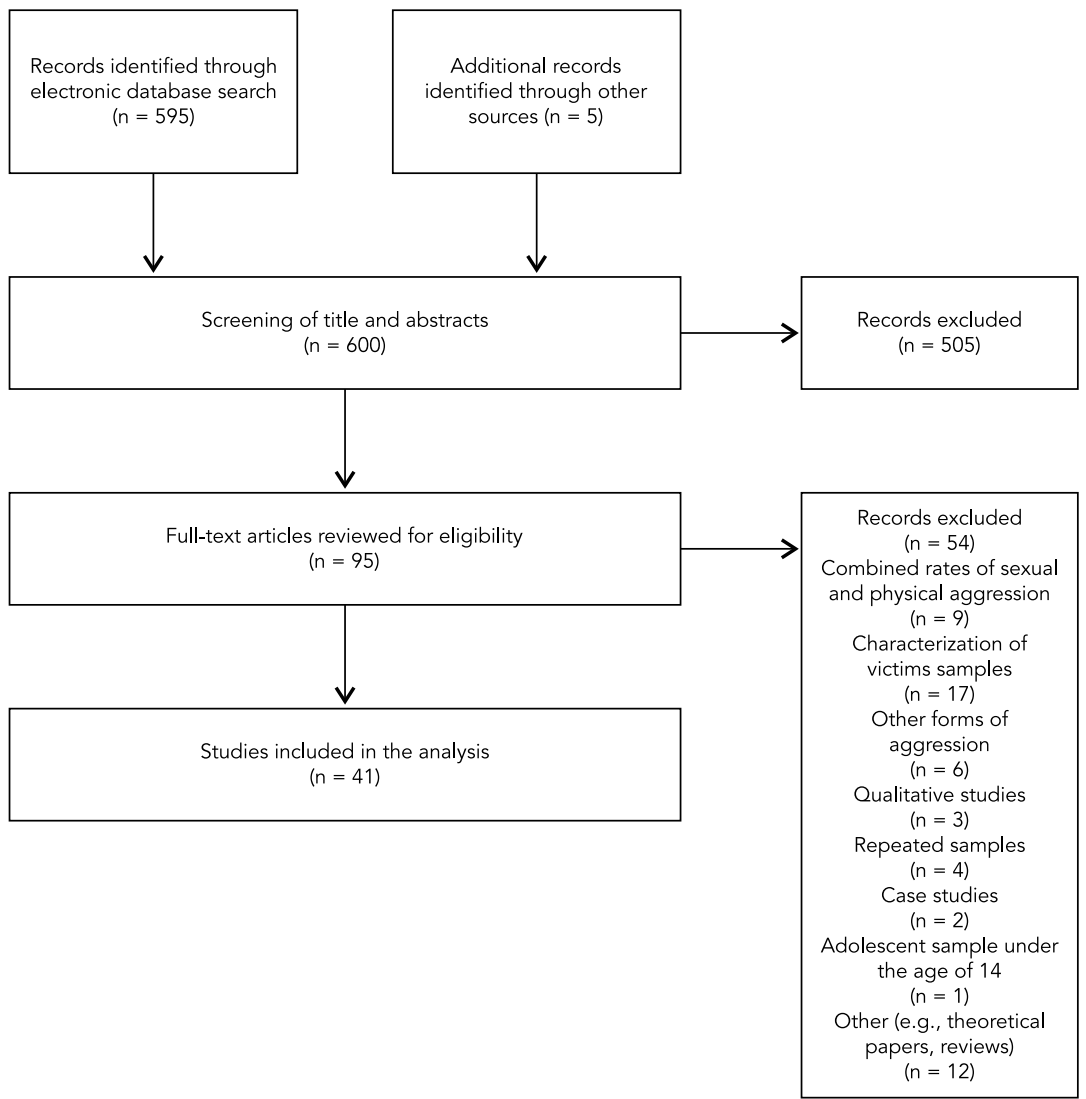


Table 1

Prevalence and incidence of self-reported sexual victimization among Brazilian samples.

\begin{tabular}{|c|c|c|c|c|}
\hline \multirow[t]{2}{*}{ Author(s) } & \multirow[t]{2}{*}{ Time window } & \multicolumn{2}{|c|}{ Sexual victimization (\%) } & \multirow[t]{2}{*}{ Perpetrator } \\
\hline & & Women & Men & \\
\hline Andrade et al. (2015) 53 * & $\begin{array}{l}\text { After diagnosis of sexually } \\
\text { transmitted disease }\end{array}$ & \multicolumn{2}{|c|}{7.2} & \\
\hline \multicolumn{5}{|c|}{ were penetrative) } \\
\hline Assis et al. (2014) $29 *$ & Lifetime & \multicolumn{2}{|c|}{1.5 for heterosexuals; 11.7 for homosexuals } & Any \\
\hline Audi et al. (2008) 21 & During pregnancy ** & 1.3 & - & Intimate partner \\
\hline Chan et al. (2008) 38 & In the previous year & 38.5 & 34.5 & Intimate partner \\
\hline D'Abreu et al. (2013) 14 & Since the age of 14 & $\begin{array}{c}29.0 \text { (any form); } 8.0 \text { (rape } \\
\text { or attempt) }\end{array}$ & $\begin{array}{c}27.0 \text { (any form); } 7.3 \text { (rape } \\
\text { or attempt) }\end{array}$ & Any \\
\hline De Moraes et al. (2006) 3 & Lifetime & 16.5 & 11.0 & Any \\
\hline \multirow[t]{2}{*}{ De Oliveira et al. (2012) 30} & Lifetime & 26.6 & 12.5 & Any \\
\hline & After the age of 18 & 14.0 & 4.0 & \\
\hline Faisal-Cury et al. (2013) 54 & Lifetime & 7.1 & - & Intimate partner \\
\hline Faúndes et al. (2000) 55 & Lifetime & $\begin{array}{c}23 \text { (any form); } 7.1 \text { (through } \\
\text { physical force or severe } \\
\text { threat) }\end{array}$ & - & Any \\
\hline Finneran et al. (2012) 35 & In the previous year & - & 2.71 & Intimate partner \\
\hline Flake et al. (2013) 40 & $\begin{array}{l}\text { During the intimate } \\
\text { partnership ** }\end{array}$ & 40.4 & 36.8 & Intimate partner \\
\hline $\begin{array}{l}\text { Fonseca-Machado et al. } \\
\text { (2015) } 25\end{array}$ & During pregnancy & 0.003 & - & Intimate partner \\
\hline $\begin{array}{l}\text { Fundação Perseu Abramo } \\
\text { (2010) } \underline{24}\end{array}$ & Lifetime & 10 (any form); 3 (rape) & - & Any \\
\hline Hines (2007) 39 & In the previous year & $\begin{array}{c}39.5 \text { (verbal coercion); } 1.3 \\
\text { (forced sex) }\end{array}$ & $\begin{array}{c}29.7 \text { (verbal coercion); } 1.4 \\
\text { (forced sex) }\end{array}$ & Intimate partner \\
\hline $\begin{array}{l}\text { Kronbauer \& Meneghel } \\
\text { (2005) } 42\end{array}$ & Lifetime & 8.0 & - & Intimate partner \\
\hline Marinheiro et al. (2006) 26 & Lifetime & 9.8 & - & Intimate partner \\
\hline Mathias et al. (2013) 37 & Lifetime & 12.4 & - & Intimate partner \\
\hline $\begin{array}{l}\text { Moraes \& Reichenheim } \\
\text { (2002) } 44\end{array}$ & During pregnancy & 7.8 & - & Intimate partner \\
\hline \multirow[t]{2}{*}{ Moura et al. (2009) 28} & Lifetime & 28.8 & - & Intimate partner \\
\hline & In the previous year & 15.5 & & \\
\hline \multirow[t]{2}{*}{ Nunes et al. (2011) 22} & Lifetime & 7.4 & - & Any \\
\hline & During pregnancy & 0.5 & & \\
\hline Oliveira \& D'Oliveira & Lifetime & $28.2 / 9.5 / 3.9$ & - & Intimate partner/Relatives/ \\
\hline (2008) 56 & In the previous year & $2.2 / 0.0 / 0.0$ & & Other aggressor \\
\hline \multirow[t]{2}{*}{ Oliveira et al. (2013) 57} & Lifetime & 7.5 & - & Any \\
\hline & Since the age of 16 & 2.9 & & \\
\hline $\begin{array}{l}\text { Oliveira Júnior \& Abdo } \\
\text { (2010) } 31\end{array}$ & Not specified & $\begin{array}{l}43.6 \text { without USB; } 56.4 \\
\text { with USB }\end{array}$ & $\begin{array}{c}17.5 \text { without USB; } 85.5 \\
\text { with USB }\end{array}$ & Not specified \\
\hline Paludo \& Schirò (2012) 32 * & Lifetime & & & $\begin{array}{c}\text { Family/Community } \\
\text { member }\end{array}$ \\
\hline Rafael \& Moura (2014) 27 & Lifetime & 39.1 & - & Intimate partner \\
\hline Reed et al. (2009) 58 & Lifetime & 36.0 & - & Any \\
\hline Rodrigues et al. (2014) 59 & During pregnancy & 0.4 & - & Intimate partner \\
\hline
\end{tabular}

(continues) 
Table 1 (continued)

\begin{tabular}{|c|c|c|c|c|}
\hline \multirow[t]{2}{*}{ Author(s) } & \multirow[t]{2}{*}{ Time window } & \multicolumn{2}{|c|}{ Sexual victimization (\%) } & \multirow[t]{2}{*}{ Perpetrator } \\
\hline & & Women & Men & \\
\hline Sabidó et al. (2015) 34 & Lifetime & - & 15.9 & Any \\
\hline Santos et al. (2009) 33 & Lifetime & $\begin{array}{c}13.2 \text { for women not living } \\
\text { with HIV; } 22.1 \text { for women } \\
\text { with HIV }\end{array}$ & - & Not clearly specified \\
\hline Schraiber et al. (2002) 60 & Since the age of 15 & 11.5 & - & Any \\
\hline Schraiber et al. (2007) 7 & Lifetime & $26.0 / 21.0$ & - & Any/Intimate partner \\
\hline & In the previous year & 16.1 & & \\
\hline Schraiber et al. (2007) 41 & Lifetime & $\begin{array}{c}10.0 \text { (Southeast); } 14.0 \\
\text { (Northeast) }\end{array}$ & - & Intimate partner \\
\hline Schraiber et al. (2008) 13 & Lifetime & 11.8 & 5.1 & Intimate partner \\
\hline Schraiber et al. (2012) 61 & Lifetime & - & 6.1 & Any \\
\hline Segurado et al. (2008) 45 & Lifetime & - & 24.1 & Any \\
\hline & Since the age of 15 & - & 11.2 & \\
\hline Silva (2003) 62 & Lifetime & 18.6 & - & Any \\
\hline Silva et al. (2011) 63 & $\begin{array}{c}\text { Before/During/After } \\
\text { pregnancy }\end{array}$ & $5.7 / 5.6 / 3.7$ & - & Intimate partner \\
\hline $\begin{array}{l}\text { Venâncio \& Fonseca } \\
\text { (2013) } 64\end{array}$ & Lifetime & 28.6 & - & Any \\
\hline Venturi et al. (2004) 23 & Lifetime & 13.0 & - & Intimate partner \\
\hline Zotareli et al. (2012) 43 & $\begin{array}{c}\text { Since the beginning of } \\
\text { college }\end{array}$ & 9.4 & - & Any \\
\hline
\end{tabular}

USB: unconventional sexual behavior.

* The authors do not provide rates for women and men separately;

** Information is not accurate.

Table 1 shows the rates of sexual victimization, defined here as the number of victims divided by the total sample. Lifetime prevalence of sexual victimization ranged from $7 \%$ to $39 \%$ in women and $5 \%$ to $16 \%$ in men. Incidence rates for the previous year varied widely. Rates in women ranged from $1.3 \%$ for forced sex to $40 \%$ for any form of sexual victimization (including partner's refusal to use a condom). The corresponding rates for men varied from $1.4 \%$ to $35 \%$.

\section{- Region}

More than a half of the studies were conducted exclusively in the Southeast of Brazil, especially in São Paulo State. Nine studies included samples of the five macro-regions of Brazil, and two other studies compared data from the Northeast with the South or Southeast (Table 2). Of those 11, only four provided data on differences between regions. One study found that female and male prevalence rates of victimization were higher in the North and Northeast, but the difference was only statistically significant in men 13 . A second study showed that the total rate of $16.7 \%$ for sexual coercion among young people in Salvador (Northeast Brazil) was significantly higher than the $10.9 \%$ in Porto Alegre (South) and $13.1 \%$ in Rio de Janeiro (Southeast) ${ }^{3}$. Two other publications also found that the South showed the lowest victimization rates, but the authors did not test the difference for statistical significance 23,24 .

\section{- Population}

Although the majority of the studies had relatively large samples, most were based on convenience samples (Table 2). Three studies used randomized samples from health service units 25,26,27 and one drew a sample from a vulnerable neighborhood 28 . Of the nine studies held in Brazil's five major regions, only one drew on a representative sample of the Brazilian population 13 , a second on a representative sample of high school sophomores 29 , and a third on a stratified sampling of psychiatric patients 30 . The other six studies, despite their large samples, were based on quota sampling (in which participants are selected according to fixed quotas based on age and rural versus urban areas) 23,24 
Table 2

Characteristics of studies on self-reported sexual victimization in Brazilian samples.

\begin{tabular}{|c|c|c|c|c|c|}
\hline Author(s) & $\begin{array}{c}\text { Data collection } \\
\text { year(s) }\end{array}$ & Region & Sampling & Population (n) & $\begin{array}{l}\text { Age in years } \\
\text { (media) }\end{array}$ \\
\hline $\begin{array}{l}\text { Andrade et al. } \\
\text { (2015) } 53\end{array}$ & 2012 & Northeast & Convenience & $\begin{array}{c}221 \text { women and men with } \\
\text { diagnosis of sexually transmitted } \\
\text { diseases * }\end{array}$ & $(30.3)$ \\
\hline $\begin{array}{l}\text { Aquino et al. } \\
\text { (2009) } 36\end{array}$ & 2006-2007 & Southeast & Convenience & 179 pregnant women * & $\geq 15(24.0)$ \\
\hline Assis et al. (2014) 29 & $2007-2008$ & 5 regions & Cluster & 3,195 high school students & $15-49$ \\
\hline Audi et al. (2008) 21 & 2004-2006 & Southeast & Convenience & 1,379 pregnant women * & $(23.8) * \star$ \\
\hline Chan et al. (2008) 38 & NS & NS & Convenience & 439 college students & (21.3) \\
\hline $\begin{array}{l}\text { D'Abreu et al. } \\
\text { (2013) } 14\end{array}$ & 2010 & Southeast & Convenience & 742 first-year college students & $\geq 18(20.1)$ \\
\hline $\begin{array}{l}\text { De Moraes et al. } \\
(2006)^{3}\end{array}$ & 2002 & $\begin{array}{l}\text { Northeast/ } \\
\text { Southeast/South }\end{array}$ & Stratified & 4,634 young women and men & $18-24$ \\
\hline $\begin{array}{l}\text { De Oliveira et al. } \\
(2012) 30\end{array}$ & 2006 & 5 regions & Stratified & 2,475 psychiatric patients * & $\geq 18$ \\
\hline $\begin{array}{l}\text { Faisal-Cury et al. } \\
\text { (2013) } 54\end{array}$ & 2006-2007 & Southeast & Convenience & $\begin{array}{c}702 \text { women receiving postpartum } \\
\text { care * }\end{array}$ & $16-44(25.0)$ \\
\hline $\begin{array}{l}\text { Faúndes et al. } \\
(2000) 55\end{array}$ & NS & Southeast & $\begin{array}{l}\text { Systematic (of } \\
\text { households of pre- } \\
\text { selected low income } \\
\text { census tracts) }\end{array}$ & 1,838 women & $15-49$ \\
\hline $\begin{array}{l}\text { Finneran et al. } \\
\text { (2012) } 35\end{array}$ & NS & NS & Convenience & 443 men who have sex with men & $\geq 18$ \\
\hline Flake et al. (2013) 40 & $2002-2003$ & Southeast & Convenience & 362 college students & $18-39(20.0)$ \\
\hline $\begin{array}{l}\text { Fonseca-Machado et } \\
\text { al. (2015) } 25\end{array}$ & $2012-2013$ & Southeast & $\begin{array}{l}\text { Systematic (of } \\
\text { women in a prenatal } \\
\text { clinic) }\end{array}$ & 358 pregnant women * & $15-43$ \\
\hline $\begin{array}{l}\text { Fundação Perseu } \\
\text { Abramo (2010) } 24\end{array}$ & 2010 & 5 regions & Quota & 2,365 women & $\geq 15$ \\
\hline Hines (2007) 39 & $2001-2006$ & Southeast & Convenience & 231 college students & $\begin{array}{c}\text { Female (20.0); Male } \\
\text { (23.0) }\end{array}$ \\
\hline $\begin{array}{l}\text { Kronbauer \& } \\
\text { Meneghel (2005) } 42\end{array}$ & 2003 & South & Convenience & 251 women * & $18-49$ \\
\hline $\begin{array}{l}\text { Marinheiro et al. } \\
(2006) 26\end{array}$ & 2002 & Southeast & $\begin{array}{l}\text { Simple random (of } \\
\text { women in a health } \\
\text { service) }\end{array}$ & 265 women * & $18-49$ \\
\hline $\begin{array}{l}\text { Mathias et al. } \\
\text { (2013) } 37\end{array}$ & 2008-2009 & Southeast & $\begin{array}{l}\text { Simple random (of } \\
\text { five basic health } \\
\text { units in each of } 15 \\
\text { municipalities of the } \\
\text { State of São Paulo) }\end{array}$ & $\begin{array}{c}\text { 2,379 women in the primary } \\
\text { healthcare network * }\end{array}$ & $18-60$ \\
\hline $\begin{array}{l}\text { Moraes \& } \\
\text { Reichenheim } \\
(2002) 44\end{array}$ & 2000 & Southeast & $\begin{array}{l}\text { Simple random (of } \\
\text { women in three } \\
\text { maternity wards) }\end{array}$ & 526 women giving birth * & NS \\
\hline Moura et al. (2009) 28 & 2007 & Central & $\begin{array}{l}\text { Systematic (of } \\
\text { households in } \\
\text { an economically } \\
\text { vulnerable urban } \\
\text { area) }\end{array}$ & $\begin{array}{c}278 \text { women from a socially } \\
\text { vulnerable area }\end{array}$ & $15-49$ \\
\hline
\end{tabular}

(continues) 
Table 2 (continued)

\begin{tabular}{|c|c|c|c|c|c|}
\hline Author(s) & $\begin{array}{c}\text { Data collection } \\
\text { year(s) }\end{array}$ & Region & Sampling & Population (n) & $\begin{array}{l}\text { Age in years } \\
\text { (media) }\end{array}$ \\
\hline Nunes et al. (2011) 22 & 2006-2007 & South & Convenience & 652 pregnant women * & $13-42(24.7) * \star \star$ \\
\hline $\begin{array}{l}\text { Oliveira \& D'Oliveira } \\
(2008) 56\end{array}$ & $2005-2006$ & Southeast & Convenience & 179 nursing staff & $20-59(37.6)$ \\
\hline $\begin{array}{l}\text { Oliveira et al. } \\
\text { (2013) } 57\end{array}$ & $2005-2006$ & Southeast & Cluster & 1,216 women & $18-65$ \\
\hline $\begin{array}{l}\text { Oliveira Júnior \& } \\
\text { Abdo (2010) } 31\end{array}$ & $2002-2003$ & 5 regions & Convenience & $\begin{array}{c}\text { 7,022 women and men with or } \\
\text { without USB }\end{array}$ & $\geq 18$ \\
\hline $\begin{array}{l}\text { Paludo \& Schirò } \\
\text { (2012) } 32\end{array}$ & NS & 5 regions & Cluster & $\begin{array}{c}\text { 7,316 low-SES young women } \\
\text { and men }\end{array}$ & $14-24$ \\
\hline $\begin{array}{l}\text { Rafael \& Moura } \\
\text { (2014) } 27\end{array}$ & $2012-2013$ & Southeast & $\begin{array}{l}\text { Simple random (of } \\
\text { women in } 4 \text { Family } \\
\text { Health Units) }\end{array}$ & 640 women * & $20-64$ \\
\hline Reed et al. (2009) 58 & 2005 & Northeast & Convenience & 377 incarcerated women & $\geq 18$ \\
\hline $\begin{array}{l}\text { Rodrigues et al. } \\
\text { (2014) } 59\end{array}$ & 2012 & Southeast & Convenience & 232 pregnant women * & $15-49(25.0)$ \\
\hline $\begin{array}{l}\text { Sabidó et al. } \\
\text { (2015) } 34\end{array}$ & $2008-2009$ & 5 regions & Driven-sampling & $\begin{array}{c}\text { 3,859 men who have sex with } \\
\text { men }\end{array}$ & $\geq 18$ \\
\hline Santos et al. (2009) 33 & $2003-2004$ & 5 regions & Convenience & $\begin{array}{l}\text { 1,777 HIV-positive women; 2,045 } \\
\text { women not living with HIV * }\end{array}$ & $\geq 18$ \\
\hline $\begin{array}{l}\text { Schraiber et al. } \\
(2002) 60\end{array}$ & 1998 & Southeast & Convenience & 322 women * & $15-49$ \\
\hline $\begin{array}{l}\text { Schraiber et al. } \\
(2007)^{7}\end{array}$ & $2001-2002$ & Southeast & Convenience & 3,193 women * & $15-49$ \\
\hline $\begin{array}{l}\text { Schraiber et al. } \\
\text { (2007) } 41\end{array}$ & $2000-2003$ & $\begin{array}{l}\text { Southeast/ } \\
\text { Northeast }\end{array}$ & Cluster & 2,128 women & $15-49$ \\
\hline $\begin{array}{l}\text { Schraiber et al. } \\
\text { (2008) } 13\end{array}$ & 1998,2005 & 5 regions & Stratified & 5,040 women and men & $16-65$ \\
\hline $\begin{array}{l}\text { Schraiber et al. } \\
(2012) 61\end{array}$ & $2002-2004$ & Southeast & Convenience & 789 men * & $18-60(36.0)$ \\
\hline $\begin{array}{l}\text { Segurado et al. } \\
\text { (2008) } 45\end{array}$ & 2001-2002 & Southeast & Convenience & $\begin{array}{l}242 \text { HIV-positive men who have } \\
\text { sex with women * }\end{array}$ & $18-71(39.0)$ \\
\hline Silva (2003) 62 & 2001 & Northeast & Cluster & 701 women * & $15-49$ \\
\hline Silva et al. (2011) 63 & 2005-2006 & Northeast & Convenience & 960 women & $18-49$ \\
\hline $\begin{array}{l}\text { Venâncio \& Fonseca } \\
\text { (2013) } 64\end{array}$ & 2011 & Southeast & Convenience & $\begin{array}{c}91 \text { women working at university } \\
\text { restaurants }\end{array}$ & $\geq 18$ \\
\hline $\begin{array}{l}\text { Venturi et al. } \\
\text { (2004) } 23\end{array}$ & 2001 & 5 regions & Quota & 2,502 women & $\geq 15$ \\
\hline $\begin{array}{l}\text { Zotareli et al. } \\
(2012) 43\end{array}$ & 2008 & Southeast & Convenience & 2,430 college students & $\begin{array}{l}62 \% \text { under the age } \\
\text { of } 25\end{array}$ \\
\hline
\end{tabular}

NS: not specified; SES: Sexual Experiences Survey; USB: unconventional sexual behavior.

* Studies with clinical samples from healthcare services;

** About $24 \%$ of the sample were adolescents, but the authors did not specify whether they were younger or older than 14 years;

$\star \star \star$ The authors did not specify how many women were 13 years old (probably a minority).

convenience sampling $31,32,33$, and respondentdriven sampling (a variation of the snowball technique in which the sample is weighted to compensate for the fact that participants are not randomly assigned) 34 , thus not meeting the criteria for statistical representativeness.
Nineteen studies included clinical samples (e.g., pregnant women, postpartum women, patients with sexually transmitted diseases, psychiatric patients, and HIV-positive men who have sex with women). Lifetime prevalence for clinical groups ranged from $7.1 \%$ to $39.1 \%$ in women and 
$6.1 \%$ to $24.1 \%$ in men. In pregnant women, rates of sexual victimization during pregnancy varied from 0.003 to 1.3. Six studies included samples of high school or college students. Twenty-six studies included women only, four studies men only, and 11 studies both women and men (Table 2). Five studies addressed same-sex sexual aggression 13,14,29,34,35, and 12 studies provided information on race issues $3,13,21,23,24,26,30,32,34,35,36,37$.

The highest victimization rates were reported by persons with unconventional sexual behavior, such as fetishism, voyeurism, incest, threesome, exhibitionism, sadomasochism, and group sex ( $56.4 \%$ for women and $85.5 \%$ for men) 31 , but this study did not specify the time window. The highest previous-year incidence rate was reported by a sample of university students (38.5\% in women and $34.5 \%$ in men) 38 . Three other studies also reported high victimization rates in university students 14,39,40.

Regarding sexual orientation, one study found that sexual victimization rates were almost eight times higher in female and male homosexuals than in heterosexuals 29 . Two other studies also observed that self-reported victimization in female and male homo- and bisexuals was slightly more frequent than in heterosexuals. However, in the first study the difference was only statistically significant in males 13 . In the second, the samples of homo- and bisexuals were too small to test for statistical significance 14 .

The results on race issues were mixed. One group of studies found that white individuals were significantly less likely to report sexual victimization $3,13,26$. A second group of studies found no significant difference in victimization rates according to skin color 21,30,34,35,36. A third group (four studies) did not test for statistical significance and found contradictory differences in rates. For example, one study found that Asian-descendant and indigenous women reported higher rates of victimization than white, brown, or black women 24 . Another study found that white and brown individuals reported higher rates than black, Asian-descendant, or indigenous persons 32 . Two other studies found that white women reported victimization less frequently than the other groups 23,37 .

\section{- Definition of sexual victimization}

The definition of sexual victimization varied widely (Table 3 ). The number and wording of questions potentially affected the resulting rates. Several studies proposed their own operationalization, using from one to five screening questions. The questionnaire adapted from the World Health Organization Multicentre Study was the most frequently used measure for assessing sexual victimization in Brazilian studies. The WHO instrument includes three questions on episodes of physically forced sexual intercourse, sexual intercourse under threat, and forced degrading sexual acts (Table 3). Two other internationally used instruments, the Revised Conflict Tactics Scales (CTS2) and the Sexual Experiences Survey (SES), were also applied to Brazilian samples.

In general, studies that considered the same time frame and used the same definition of sexual aggression found comparable data. For example, using the same instrument to assess sexual victimization, two studies in the five major regions of Brazil found similar rates of lifetime female sexual victimization (13\% in 200423 and $10 \%$ in 2010 24). Studies that used CTS2 in university students also found similar previous-year incidence rates, ranging from $39 \%$ to $40 \%$ in women and $30 \%$ to $37 \%$ in men $38,39,40$. Of the twelve studies that adopted the WHO questionnaire, three found similar lifetime prevalence rates for sexual victimization, varying from $9.8 \%$ to $11.8 \%$ in São Paulo State 13,26,41. However, the rates were slightly lower in the South (8\% in Porto Alegre 42 ) and slightly higher in the Northeast (14.3\% in the Zona da Mata region of Pernambuco State ${ }^{41}$ ). Rates were also considerably higher in economically vulnerable areas, e.g., $28.8 \%$ in a community sample in Brasília (Central) 28 and 26\% in a large clinical sample in São Paulo 7 .

\section{Self-reported perpetration of sexual aggression by women and men}

Available data on perpetration of sexual aggression in Brazil are still very limited. A total of nine studies addressed the incidence or prevalence of self-reported sexual aggression (Table 4). Of these, two investigated lifetime prevalence of sexual aggression. The other seven studies investigated sexual aggression using different time frames, such as in the previous year, after age 14, after age 18, during pregnancy, since starting university, and during an intimate relationship.

Regarding study population, five studies involved community samples and four involved clinical samples. Two studies included female respondents only, three studies included men and women, and four studies included men only. Specific social groups were addressed by seven studies: university students $14,38,40,43$, pregnant women ${ }^{44}$, men who have sex with men ${ }^{35}$, and HIV-positive men who have sex with women 45.

Rates varied from $2 \%$ to $44 \%$ in men and from $3 \%$ to $32 \%$ in women. However, differences in time frames and whether the aggression was 
Table 3

Definition of sexual victimization by studies that investigated the frequency of self-reported sexual victimization in Brazilian samples

\begin{tabular}{|c|c|}
\hline Author(s) & Operationalization of sexual victimization \\
\hline Andrade et al. (2015) 53 & Questionnaire adapted from the World Health Organization Multicentre Study * \\
\hline Aquino et al. (2009) 36 & $\begin{array}{l}\text { Attempted or actual contact between penis and vulva or penis and anus involving any degree of penetration; } \\
\text { penetration of anal or genital opening using a hand, finger, or any other object; contact between mouth and } \\
\text { penis, vulva or anus; direct or indirect (through clothes) intentional touch of genitals, anus, groin, breasts, internal } \\
\text { thighs, or buttocks; or acts with no physical contact but of a sexual nature such as voyeurism and exposure to } \\
\text { pornography }\end{array}$ \\
\hline Assis et al. (2014) 29 & Not specified \\
\hline Audi et al. (2008) 21 & $\begin{array}{l}\text { Forced to have some form of sexual intercourse against their wishes; had sexual intercourse because they felt } \\
\text { afraid to refuse the partner's request }\end{array}$ \\
\hline Chan et al. (2008) 38 ** & Revised Conflict Tactics Scales (CTS2) \\
\hline D'Abreu et al. (2013) $14 * \star$ & Short form of Sexual Experiences Survey (SES) \\
\hline De Moraes et al. (2006) ${ }^{3}$ & "Has anybody tried to force you to have sexual relations against your will?" \\
\hline De Oliveira et al. (2012) 30 & Forced to have unwanted sex; suffered any kind of abuse of sexual nature against their will \\
\hline Faisal-Cury et al. (2013) 54 & Questionnaire adapted from the World Health Organization Multicentre Study * \\
\hline Faúndes et al. (2000) 55 & Coerced to have sex; threatened or physically forced to have sex \\
\hline Finneran et al. (2012) $35 * \star$ & $\begin{array}{c}\text { "Have any of your partners ever used physical force or verbal threats to force you to have sex when you did not } \\
\text { want to?" }\end{array}$ \\
\hline Flake et al. (2013) 40 ** & Revised Conflict Tactics Scales (CTS2) \\
\hline Fonseca-Machado et al. (2015) 25 & Questionnaire adapted from the World Health Organization Multicentre Study * \\
\hline Fundação Perseu Abramo (2010) 24 & $\begin{array}{c}\text { "He forced you to have sex when you did not want it"; "He forced you into sexual acts that you did not like"; "He } \\
\text { raped you" }\end{array}$ \\
\hline Hines (2007) 39 & Revised Conflict Tactics Scales (CTS2) \\
\hline Kronbauer \& Meneghel (2005) 42 & Questionnaire adapted from the World Health Organization Multicentre Study * \\
\hline Marinheiro et al. (2006) 26 & Questionnaire adapted from the World Health Organization Multicentre Study * \\
\hline Mathias et al. (2013) 37 & Questionnaire adapted from the World Health Organization Multicentre Study * \\
\hline Moraes \& Reichenheim (2002) 44 ** & Revised Conflict Tactics Scales (CTS2) \\
\hline Moura et al. (2009) 28 & Questionnaire adapted from the World Health Organization Multicentre Study * \\
\hline Nunes et al. (2011) 22 & "Has anyone forced you into sex acts?" \\
\hline Oliveira \& D'Oliveira (2008) 56 & Questionnaire adapted from the World Health Organization Multicentre Study * \\
\hline Oliveira et al. (2013) 57 & $\begin{array}{l}\text { Before you were } 16 \text { years old (age } 15 \text { or younger), did someone in your family try to make you do sexual things or } \\
\text { watch sexual things?; Before you were } 16 \text { years old (age } 15 \text { or younger), did someone other than a family member } \\
\text { try to make you do sexual things or watch sexual things?; Since the age of } 16 \text { ( } 16 \text { or older), was there a time when } \\
\text { someone forced you to engage in sex acts that you really did not want? }\end{array}$ \\
\hline Oliveira Júnior \& Abdo (2010) 31 & Not specified \\
\hline Paludo \& Schirò (2012) 32 & "Tried to touch my body"; "Touched my body"; "Had forced sexual relations" \\
\hline Rafael \& Moura (2014) $27 * \star$ & Revised Conflict Tactics Scales (CTS2) \\
\hline Reed et al. (2009) 58 & $\begin{array}{l}\text { Touched by another person in a sexual way or forced to touch another person sexually when she did not want to; } \\
\text { forced to have sex with another person; ever forced to do something sexual with another person when they did } \\
\text { not want to }\end{array}$ \\
\hline Rodrigues et al. (2014) 59 & Not specified \\
\hline Sabidó et al. (2015) 34 & Being forced to have sex against his will \\
\hline Santos et al. (2009) 33 & Not specified \\
\hline Schraiber et al. (2002) 60 & Not specified \\
\hline Schraiber et al. (2007) 7 & Questionnaire adapted from the World Health Organization Multicentre Study * \\
\hline Schraiber et al. (2007) 41 & Questionnaire adapted from the World Health Organization Multicentre Study * \\
\hline Schraiber et al. (2008) 13 & Questionnaire adapted from the World Health Organization Multicentre Study * \\
\hline  & Has anyone ever forced you to have sexual intercourse when you did not want to? \\
\hline
\end{tabular}

(continues) 
Table 3 (continued)

\begin{tabular}{|c|c|}
\hline Author(s) & Operationalization of sexual victimization \\
\hline Segurado et al. (2008) $45 * \star$ & Forced by someone to have sex unwillingly \\
\hline Silva (2003) 62 & "Has anyone ever forced you to have sex against your will?" \\
\hline Silva et al. (2011) 63 & Questionnaire adapted from the World Health Organization Multicentre Study * \\
\hline Venâncio \& Fonseca (2013) 64 & Not specified \\
\hline Venturi et al. (2004) 23 & $\begin{array}{c}\text { "He forced you to have sex when you did not want it"; "He forced you into sexual acts that you did not like"; "He } \\
\text { raped you" }\end{array}$ \\
\hline Zotareli et al. (2012) 43 ** & $\begin{array}{l}\text { Having been physically forced to have sexual intercourse against their will; Having had sexual intercourse because } \\
\text { they were afraid of what the aggressor might do; Having had sexual intercourse despite not wanting to because of } \\
\text { a belief that it was the aggressor's right; Having been forced to subject themselves to a degrading or humiliating } \\
\text { sexual act; Someone having agreed to use a condom during intercourse but failed to comply with this agreement; } \\
\text { Someone having refused to use a condom during sexual intercourse }\end{array}$ \\
\hline
\end{tabular}

\footnotetext{
* This questionnaire includes 3 questions: (1) Has he/she physically forced you to have sexual intercourse when you did not want to?; (2) Did you ever have sexual intercourse when you did not want to because you were afraid of what he/she might do?; and (3) Has he/she forced you to do something sexual that you found degrading or humiliating?;

** These studies addressed both victimization and perpetration. In order to assess self-reported perpetration, they used parallel versions for perpetration from the items described in this table;

*** This paper also addressed perpetration. For the perpetration version, two questions were asked: (1) Have you ever forced your partner to have sexual relations when she did not want to? and (2) Have you ever forced your partner to do certain sexual practices that she did not like?
}

Table 4

Prevalence and incidence of self-reported perpetration of sexual aggression in Brazilian samples.

\begin{tabular}{|c|c|c|c|c|}
\hline \multirow[t]{2}{*}{ Author(s) } & \multirow[t]{2}{*}{ Time window } & \multicolumn{2}{|c|}{ Sexual perpetration (\%) } & \multirow[t]{2}{*}{ Victims } \\
\hline & & Women & Men & \\
\hline Chan et al. (2008) 38 & In the previous 12 months & 28.9 & 43.7 & Intimate partner \\
\hline D'Abreu et al. (2013) 14 & Since the age of 14 & 3.0 & 33.7 & Any \\
\hline Finneran et al. (2012) 35 & In the previous year & - & 1.81 & Intimate partner \\
\hline Flake et al. (2013) 40 & During the intimate partnership & 31.6 & 39.1 & Intimate partner \\
\hline Moraes \& Reichenheim (2002) 44 * & During pregnancy & 4.7 & - & Intimate partner \\
\hline Rafael \& Moura (2014) 27 * & Lifetime & 14.3 & - & Intimate partner \\
\hline Schraiber et al. (2012) 61 * & Since the age of 18 & - & 3.9 & Intimate partner \\
\hline Segurado et al. (2008) 45 * & Lifetime & - & 5.8 & Any \\
\hline Zotareli et al. (2012) 43 & Since the beginning of college & - & 3.3 & Any \\
\hline
\end{tabular}

Note: all studies addressed both sexual victimization and perpetration. More information on the operationalization of perpetration of sexual aggression, region and characteristics of the sample can be found in Tables 2 and 3 .

* Studies with clinical samples of healthcare services.

committed against intimate partners or against any persons limit the data's comparability.

Differences in perpetration rates according to sexual orientation and skin color were also addressed. One study found that female and male bisexuals and male homosexuals were more likely to report perpetration than heterosexuals. However, the authors did not test for statistical significance 14 . Two other studies found that skin color was not significantly associated with perpetration 43,45 .

\section{Discussion}

Sexual aggression has attracted increasing political attention and scientific research in Brazil since 2000. Using self-report methods, research- 
ers have identified sexual victimization in the general population and in community and clinical samples. A review of such studies is important for obtaining more realistic rates, showing that law enforcement and medical records are limited and may have misdirected public policies addressing the problem of sexual aggression.

The current article reviewed studies on the incidence and prevalence of self-reported sexual aggression and victimization among women and men in Brazil. Despite the heterogeneity of methods and limited comparability of data, the review showed that sexual aggression is a pervasive problem in young adulthood 3,14,29,38,39,40,43 and is much more prevalent than identified by official data. Studies that used the same definition of sexual victimization and same time interval showed comparable rates, suggesting consistency of the instrument across samples. Differences in rates among studies that used the same instrument could be attributed to other factors, such as time frame, location, and socioeconomic vulnerability. For example, people from the North and Northeast of Brazil or who lived in economically deprived areas were more likely to report sexual victimization 7,13,28.

Concerning gender, most studies focused on female victimization. Nevertheless, an increasing number of studies have addressed male victimization in the last decade. Studies on self-reported perpetration are still few, especially among women. Despite the myth that men can only be sexually coerced by other men 46 , the majority of men who report victimization are heterosexuals and mostly report that their aggressors are women 3,14 . However, the percentage of victimization was higher in male homosexuals and bisexuals than in heterosexuals 13,14,29. Still, regardless of sexual orientation, victimization in men has been ignored for some time by researchers and authorities. Male victimization does not minimize or justify male aggression against women, which is highly prevalent and appears to have more severe consequences than the opposite case 47 , but this shows that public health professionals should be aware of male victimization and that health services should be prepared to receive and treat male victims.

The findings were inconclusive concerning an association between sexual aggression and skin color. The studies were not clear on their definition of skin color, especially in a country like Brazil with a strong history of miscegenation. Some studies only adopted a dichotomy (white vs. non-white; or black vs. non-black), making impossible to identify other groups such as brown, indigenous, or Asian-descendant. The review's findings also contrast with those provided by official medical records 2 , according to which, in Brazil, white and brown women are the most likely to be rape victims.

High incidence rates for sexual victimization in university students corroborate the international literature that this group may be at increased risk of sexual aggression ${ }^{48}$. Brazilian studies found the highest incidence rates of victimization in this group. However, it was not possible to say with certainty that this group is at greater risk than the general population, for two reasons: the two samples were not compared to each other, and the rates were obtained by different measures. Higher victimization rates in university students could be attributed to the instruments used, like CTS2 and SES 14,38,39,40. These instruments consist of multiple items with behaviorally specific descriptions of unwanted sexual acts, which prevents vagueness. For example, instead of asking, "Have you ever been raped?", the SES applies thorough descriptions of behaviors that correspond to the legal definition of rape (e.g. "A man put his penis, or someone put their fingers or objects into my vagina without my consent", "A man put his penis, or someone put their fingers or objects into my anus without my consent?", and "Someone had oral sex with me or made me have oral sex with them without my consent") 16. Another advantage of these two instruments is that they assessed coercive acts that were usually neglected by other studies, such as verbal coercion (e.g., insistence, threat to spread rumors about the victim's sexuality), taking advantage of victims incapacitated state (e.g., when the victim was intoxicated and unable to defend her/himself) 16 , and refusal by the partner to use a condom during sexual intercourse 38 . The more inclusive and meticulous definitions of sexual aggression may partly explain the inflated rates in university students.

The results of the present review allow identifying some gaps in Brazilian research on sexual aggression. First, the majority of studies in Brazil relied on convenience samples, which provide results that cannot be generalized to the overall Brazilian population. Random selection of participants from a health service or from a vulnerable neighborhood also does not make the sample representative of all health services or vulnerable neighborhoods, much less of the general population. Randomly chosen respondents from a single health service makes up a representative sample of the users of that service only. Besides, more than a half of the studies were conducted exclusively in the Southeast, the richest region of the country and where research institutes are concentrated, revealing the imbalance of available information on self-reported sexual 
aggression and victimization across the five major geographic regions. Second, sexual orientation and race were occasionally addressed, but it is still unclear how they might be related to vulnerability. Third, many studies were unable to differentiate between sexual abuse (before age 14) and sexual aggression in adulthood (after age 14). Although childhood sexual abuse may act as a risk factor for later sexual victimization 49 , the two phenomena relate to distinct underlying mechanisms. Fourth, in addition to the lack of information on time frame, location, and sample age, some studies failed to provide clear information on how they defined sexual aggression. Other studies applied only a single or a few screening questions. These short instruments tend to use generic terms like "being forced" or "being raped", which leave room for interpretation and may elicit lower rates 50 . Respondents might have disregarded other forms of aggressive sexual acts (e.g., taking advantage of a victim's inebriation), although such behaviors would legally qualify as rape. The use of behaviorally specific descriptions of coercive acts prevents ambiguity and ensures more accurate data 16,50 .

To address those gaps and better orient public policies, I outline some suggestions for future research in Brazil: (1) self-report studies on sexual aggression and victimization with representative samples of the Brazilian population, identifying the differences across the five major geographic regions; (2) studies that address sexual aggression from a developmental and longitudinal perspective, from young age until late adulthood, seeking to understand the onset, severity, and persistence of the problem over the years; few Brazilian studies have addressed sexual victimization and perpetration prospectively 49,51 ;
(3) studies that differentiate between childhood sexual abuse and sexual aggression i.e., sexual victimization before and after age 14 , respectively; (4) studies that address sexual aggression and victimization in both men and women, taking sexual orientation and skin color into consideration; (5) studies that address incidence of sexual aggression in the previous year, using a behaviorally specific description of the legal definition of rape in Brazil, such as proposed by SES 16, so that rates can be directly compared to the official data on rape in Brazil; (6) studies that confirm if, and explain why, specific social groups (e.g., homosexuals and bisexuals, and university students) may have higher vulnerability for sexual victimization and perpetration.

Rape and other forms of sexual aggression involve enormous costs, including medical (pain, HIV, pregnancy), psychological (fear, distress), and social and economic (absenteeism, reduced earning capacity) 52 . From a public health perspective, sexual aggression should be understood as a continuum of violence that threatens the well-being of victims. Police and medical records in Brazil fail to account for the victims that are of special public health interest: those who do not or cannot access medical care and the justice system, but who may be in need of help. If sexual aggression is underreported, numerous victims remain subjected to physical, mental, and social trauma without receiving any form of medical, psychological, or legal support. Public health should address the huge gap between official data and the problem's real scope in Brazil and advocate for population-based policies that facilitate victims' access to the health and legal system.

\section{Acknowledgments}

The author is grateful to John Wilson, MD, for revising the final version. 


\section{References}

1. Sistema Nacional de Informações de Segurança Pública. Relatório consolidado de ocorrências de estupros registrados pela Polícia Civil. https:// www.sinesp.gov.br/estatisticas-publicas (accessed on $22 / \mathrm{Feb} / 2016$ ).

2. Cerqueira D, Coelho D. Estupro no Brasil: uma radiografia segundo os dados da saúde. http:// www.fiepr.org.br/nospodemosparana/uploadA ddress/140327__Estupro_no_Brasil_uma_radio grafia_segundo_dados_da_saude[51345].pdf (accessed on 22/Feb/2016).

3. Moraes CL, Cabral CS, Heilborn ML. Magnitude e caracterização de situações de coerção sexual vivenciadas por jovens de três grandes capitais brasileiras: Porto Alegre, Rio de Janeiro e Salvador. Cad Saúde Pública 2006; 22:1493-504.

4. Villela WV, Lago T. Conquistas e desafios no atendimento das mulheres que sofreram violência sexual. Cad Saúde Pública 2007; 23:471-5.

5. Monteiro CF, Morais SC, Ferreira MT, Carvalho RX, Canuto MA, Moreira IC. Conhecimento dos enfermeiros sobre o serviço de atenção às mulheres vítimas de violência sexual. Rev Bras Enferm 2008; 61:454-8.

6. de Oliveira MT, Samico I, Ishigami AB, Nascimento RM. Violência intrafamiliar: a experiência dos profissionais de saúde nas Unidades de Saúde da Família de São Joaquim do Monte, Pernambuco. Rev Bras Epidemiol 2012; 15:166-78.

7. Schraiber LB, D'Oliveira AF, Couto MT, Hanada H, Kiss LB, Durand JG, et al. Violência contra mulheres entre usuárias de serviços públicos de saúde da Grande São Paulo. Rev Saúde Pública 2007; 41: 359-67.

8. Krug EG, Dahlberg LL, Mercy JA, Zwi AB, Lozano R. The world report on violence and health. Geneva: World Health Organization; 2002.

9. Kruttschnitt C, Kalsbeek WD, House CC, editors. Estimating the incidence of rape and sexual assault. Washington DC: National Academies Press; 2014.

10. Jewkes R, Abrahams N. The epidemiology of rape and sexual coercion in South Africa: an overview. Soc Sci Med 2002; 55:1231-44.

11. Gupta A. Reporting and incidence of violence against women in India, 2014. http://riceinsti tute.org/wordpress/wp-content/uploads/down loads/2014/10/Reporting-and-incidence-of-vio lence-against-women-in-India-working-paperfinal.pdf (accessed on 19/Feb/2016).

12. Ministério da Saúde. Tratamento dos agravos resultantes da violência sexual contra mulheres e adolescentes. 2a Ed. Brasília: Ministério da Saúde; 2005.

13. Schraiber LB, D'Oliveira AF, Franca Junior I. Violência sexual por parceiro íntimo entre homens e mulheres no Brasil urbano, 2005. Rev Saúde Pública 2008; 42 Suppl 1:127-37.

14. D'Abreu LC, Krahé B, Bazon MR. Sexual aggression among Brazilian college students: prevalence of victimization and perpetration in men and women. J Sex Res 2013; 50:795-807.
15. Brasil. Lei no 12.015, de 7 de agosto de 2009. Diário Oficial da União 2009; 10 ago.

16. Koss MP, Abbey A, Campbell R, Cook S, Norris J, Testa M, et al. Revising the SES: a collaborative process to improve assessment of sexual aggression and victimization. Psychol Women Q 2007; 31:357-70.

17. Temkin J. Rape and the criminal justice system. Aldershot: Dartmouth; 1995.

18. Koss MP, Gidycz CA, Wisniewski N. The scope of rape: incidence and prevalence of sexual aggression and victimization in a national sample of higher education students. J Consult Clin Psychol 1987; 55:162-70.

19. Barker C, Pistrang N, Elliott R. Research methods in clinical psychology: an introduction for students and practitioners. 2nd Ed. Chichester: John Wiley \& Sons; 2002.

20. Kolivas ED, Gross AM. Assessing sexual aggression: addressing the gap between rape victimization and perpetration prevalence rates. Aggress Violent Behav 2007; 12:315-28.

21. Audi CA, Segall-Correa AM, Santiago SM, Andrade MG, Perez-Escamila R. Violence against pregnant women: prevalence and associated factors. Rev Saúde Pública 2008; 42:877-85.

22. Nunes MA, Camey S, Ferri CP, Manzolli P, Manenti $\mathrm{CN}$, Schmidt MI. Violence during pregnancy and newborn outcomes: a cohort study in a disadvantaged population in Brazil. Eur J Public Health 2011; 21:92-7.

23. Venturi G, Recamán M, de Oliveira S, Rago M. A mulher brasileira nos espaços público e privado. São Paulo: Fundação Perseu Abramo; 2004.

24. Fundação Perseu Abramo. Mulheres brasileiras e gênero nos espaços público e privado. http:// www.fpabramo.org.br/sites/default/files/pesqui saintegra.pdf (accessed on 04/Aug/2015).

25. Fonseca-Machado MO, Alves LC, Monteiro JC, Stefanello J, Nakano AM, Haas VJ, et al. Depressive disorder in pregnant Latin women: does intimate partner violence matter? J Clin Nurs 2015; 24: 1289-99.

26. Marinheiro ALV, Vieira EM, Souza LD. Prevalência da violência contra a mulher usuária de serviço de saúde. Rev Saúde Pública 2006; 40:604-10.

27. Rafael RMR, Moura ATMS. Violência contra a mulher ou mulheres em situação de violência? Uma análise sobre a prevalência do fenômeno. J Bras Psiquiatr 2014; 63:149-53.

28. Moura LB, Gandolfi L, Vasconcelos AM, Pratesi R. Intimate partner violence against women in an economically vulnerable urban area, Central-West Brazil. Rev Saúde Pública 2009; 43:944-53.

29. Assis SG, Gomes R, Pires TO. Adolescence, sexual behavior and risk factors to health. Rev Saúde Pública 2014; 48:43-51.

30. de Oliveira HN, Machado CJ, Guimaraes MD. Factors associated with self-report of sexual violence against men and women with mental disorders in Brazil. Soc Psychiatry Psychiatr Epidemiol 2012 47:1567-79. 
31. Oliveira Junior WM, Abdo CH. Unconventional sexual behaviors and their associations with physical, mental and sexual health parameters: a study in 18 large Brazilian cities. Rev Bras Psiquiatr 2010 32:264-74.

32. Paludo SS, Schirò EDB. Um estudo sobre os fatores de risco e proteção associados à violência sexual cometida contra adolescentes e jovens adultos. Estud Psicol (Natal) 2012; 17:397-404.

33. Santos NJ, Barbosa RM, Pinho AA, Villela WV, Aidar T, Filipe EM. Contextos de vulnerabilidade para o HIV entre mulheres brasileiras. Cad Saúde Pública 2009; 25 Suppl 2:S321-33.

34. Sabidó M, Kerr LR, Mota RS, Benzaken AS, Pinho AA, Guimarães MD, et al. Sexual violence against men who have sex with men in Brazil: a respondent-driven sampling survey. AIDS Behav 2015; 19:1630-41.

35. Finneran C, Chard A, Sineath C, Sullivan P, Stephenson R. Intimate partner violence and social pressure among gay men in six countries. West J Emerg Med 2012; 13:260-71.

36. Aquino NM, Sun SY, Oliveira EM, Martins MG, Silva JF, Mattar R. Sexual violence and its association with health self-perception among pregnant women. Rev Saúde Pública 2009; 43:954-60.

37. Mathias AK, Bedone A, Osis MJ, Fernandes AM. Perception of intimate partner violence among women seeking care in the primary healthcare network in São Paulo state, Brazil. Int J Gynaecol Obstet 2013; 121:214-7.

38. Chan KL, Straus MA, Brownridge DA, Tiwari A, Leung WC. Prevalence of dating partner violence and suicidal ideation among male and female university students worldwide. J Midwifery Womens Health 2008; 53:529-37.

39. Hines DA. Predictors of sexual coercion against women and men: a multilevel, multinational study of university students. Arch Sex Behav 2007; 36:403-22.

40. Flake TA, Barros C, Schraiber LB, Menezes PR. Intimate partner violence among undergraduate students of two universities of the state of Sao Paulo, Brazil. Rev Bras Epidemiol 2013; 16:801-16.

41. Schraiber LB, D'Oliveira AF, Franca-Junior I, Diniz S, Portella AP, Ludermir AB, et al. Prevalence of intimate partner violence against women in regions of Brazil. Rev Saúde Pública 2007; 41:797-807.

42. Kronbauer JF, Meneghel SN. Profile of gender violence by intimate partners. Rev Saúde Pública 2005; 39:695-701.

43. Zotareli V, Faúndes A, Osis MJD, Duarte GA, Sousa $\mathrm{MH}$. Gender and sexual violence among students at a Brazilian university. Rev Bras Saúde Matern Infant 2012; 12:37-46.

44. Moraes CL, Reichenheim ME. Domestic violence during pregnancy in Rio de Janeiro, Brazil. Int J Gynaecol Obstet 2002; 79:269-77.

45. Segurado AC, Batistella E, Nascimento V, Braga PE, Filipe E, Santos N, et al. Sexual abuse victimisation and perpetration in a cohort of men living with HIV/AIDS who have sex with women from São Paulo, Brazil. AIDS Care 2008; 20:15-20.
46. Coxell AW, King MB. Male victims of rape and sexual abuse. J Sex Marital Ther 1996; 11:297-308.

47. Krahé B, Scheinberger-Olwig R, Bieneck S. Men's reports of nonconsensual sexual interactions with women: prevalence and impact. Arch Sex Behav 2003; 32:165-75.

48. Kilpatrick DG, Resnick HS, Ruggiero KJ, Conoscenti LM, McCauley J. Drug-facilitated, incapacitated, and forcible rape: a national study. Charleston: National Crime Victims Research \& Treatment Center, Medical University of South Carolina; 2007.

49. D’Abreu LC, Krahé B. Vulnerability to sexual victimization in female and male college students in Brazil: cross-sectional and prospective evidence. Arch Sex Behav 2015; 45:1101-15.

50. Koss MP. Detecting the scope of rape: a review of prevalence research methods. J Interpers Violence 1993; 8:198-222.

51. D’Abreu LCF, Krahé B. Predicting sexual aggression in male college students in Brazil. Psychol Men Masc 2014; 15:152-62.

52. Waters H, Hyder A, Rajkotia Y, Basu S, Rehwinkel JA. The economic dimensions of interpersonal violence. Geneva: Department of Injuries and Violence Prevention, World Health Organization; 2004.

53. Andrade RF, Araujo MA, Vieira LJ, Reis CB, Miranda AE. Intimate partner violence after the diagnosis of sexually transmitted diseases. Rev Saúde Pública 2015; 49:3.

54. Faisal-Cury A, Menezes PR, d'Oliveira AF, Schraiber LB, Lopes CS. Temporal relationship between intimate partner violence and postpartum depression in a sample of low income women. Matern Child Health J 2013; 17:1297-303.

55. Faúndes A, Hardy E, Osis MJ, Duarte G. O risco para queixas ginecológicas e disfunções sexuais segundo história de violência sexual. Rev Bras Ginecol Obstet 2000; 22:153-7.

56. Oliveira AR, D'Oliveira AF. Gender-violence against the female nursing staff of a Brazilian hospital in Sao Paulo City. Rev Saúde Pública 2008; 42:868-76.

57. Oliveira JB, Kerr-Correa F, Lima MC, Bertolote JM, Tucci AM. Sexual abuse and alcohol use among women in metropolitan São Paulo, Brazil: a general population study. Rev Bras Epidemiol 2013; 16:817-25

58. Reed E, Raj A, Falbo G, Caminha F, Decker MR, Kaliel DC, et al. The prevalence of violence and relation to depression and illicit drug use among incarcerated women in Recife, Brazil. Int J Law Psychiatry 2009; 32:323-8.

59. Rodrigues DP, Gomes-Sponholz FA, Stefanelo J, Nakano AM, Monteiro JC. Violência do parceiro íntimo contra a gestante: estudo sobre as repercussões nos resultados obstétricos e neonatais. Rev Esc Enferm USP 2014; 48:206-13.

60. Schraiber LB, d'Oliveira AF, Franca Jr. I, Pinho AA. Violência contra a mulher: estudo em uma unidade de atenção primária à saúde. Rev Saúde Pública 2002; 36:470-7. 
61. Schraiber LB, Barros CR, Couto MT, Figueiredo WS, Albuquerque FP. Men, masculinity and violence: a study in primary health care services. Rev Bras Epidemiol 2012; 15:790-803.

62. Silva IV. Violência contra mulheres: a experiência de usuárias de um serviço de urgência e emergência de Salvador, Bahia, Brasil. Cad Saúde Pública 2003; 19 Suppl 2:S263-72.

\section{Resumo}

A falta de dados oficiais sobre estupro tem desafiado pesquisadores no Brasil. Dois estudos recentes utilizaram dados de boletins policiais e prontuários médicos. Embora esses estudos sejam avanços importantes na pesquisa sobre estupro no Brasil, apresentam algumas limitações. Para obter taxas mais realistas, este artigo faz uma revisão das pesquisas brasileiras sobre agressão e vitimização sexual em indivíduos com mais de 14 anos de idade. Foram identificados 41 estudos através de buscas eletrônicas e verificação de referências bibliográficas. Entre 1\% e 40\% de mulheres e 1\% e 35\% de homens relataram alguma forma de vitimização no ano anterior à entrevista. A incidência de homens perpetradores de agressão sexual variava de $2 \%$ a $44 \%$. Apesar da grande variabilidade, essas taxas são muito mais altas do que aquelas estimadas a partir de dados oficiais. Os resultados sugerem uma associação entre orientação sexual e vulnerabilidade. Os resultados variaram em relação à raça. A maioria dos estudos era baseada em amostras de conveniência e focava a vitimização feminina. A vitimização masculina vem recebendo mais atenção, mas ainda há poucos estudos sobre a perpetração auto-relatada.

Violência Sexual; Estupro; Vítimas de Crime
63. Silva EP, Ludermir AB, Araujo TV, Valongueiro SA. Frequency and pattern of intimate partner violence before, during and after pregnancy. Rev Saúde Pública 2011; 45:1044-53.

64. Venâncio KC, Fonseca RM. Mulheres trabalhadoras de restaurantes universitários: condições de vida, trabalho e violência de gênero. Rev Esc Enferm USP 2013; 47:1016-24.

\section{Resumen}

La falta de datos oficiales sobre la violación ha desafiado a los investigadores en Brasil. Dos estudios recientes han utilizado los datos de los informes policiales y los registros médicos. Aunque estos estudios son importantes avances en la investigación sobre la violación en Brasil, tienen algunas limitaciones. Para obtener tasas más realistas, el artículo hace una revisión de las investigaciones brasileñas sobre la agresión y la victimización sexual en los individuos mayores de 14 años. Se identificaron 41 estudios mediante búsquedas electrónicas y verificación de referencias. Entre el $1 \%$ y el $40 \%$ de las mujeres y el $1 \%$ y el $35 \%$ de los hombres informaron alguna forma de victimización en el año anterior a la entrevista. La incidencia de los hombres autores de agresión sexual varió de $2 \%$ a 44\%. A pesar de la gran variabilidad, las tasas son mucho más altas que las estimadas a partir de datos oficiales. Los resultados sugieren una asociación entre la orientación sexual y la vulnerabilidad. Los resultados variaron según la raza. La mayoría de los estudios se basaron en muestras de conveniencia y se centró en la victimización femenina. La victimización masculina está recibiendo más atención, pero hay pocos estudios sobre la perpetración autoinformada.

Violencia Sexual; Violación; Victimas de Crimen
Submitted on $07 /$ Aug/2015

Final version resubmitted on 14/Mar/2016 Approved on 02/May/2016 